\title{
Biomotor Profile of Basketball Athletes Aged Under 16 Years
}

\author{
Fakhri Fajrin Kurniawan ${ }^{1}$, Nur Khoiriyah ${ }^{2}$ \\ \{fakhry.fajrin@umc.ac.id1, nurkhoiriyah@umc.ac.id2\} \\ Cirebon Muhammadiyah University, Cirebon, Indonesia ${ }^{1,2}$
}

\begin{abstract}
This study aimed to determine the biomotor profile of basketball athletes aged under 16 years in the Cirebon Region in 2020. The samples consisted of 20 basketball athletes aged under 16 years selected using the purposive sampling technique. The biomotor profile was analyzed using the $\mathrm{T}$ score. The $\mathrm{T}$ score showed that the biomotor profile of athletes in the very poor category was $7.69 \%$, in the poor category was $15.38 \%$, in the moderate category was $38.46 \%$, in the good category was $23.08 \%$, and in the very good category was $15.38 \%$. Furthermore, the result of the biomotor profile based on the average value was in the moderat category. Both the coaches and athletes need to increase the training hours, especially in terms of practicing basketball techniques related to biomotor improvement.
\end{abstract}

Keywords: Athlete aged under 16 years, basketball, biomotor profile.

\section{Introduction}

Basketball is a team sport that consists of five players in each team. Many aspects need to be emphasized in basketball, such as (1) physical aspects (the more dominant physical component is stamina); (2) technical aspects (technical fundamentals in basketball are shooting, passing, and dribbling); (3) strategy aspects (the basic strategies used in basketball are the pattern of defense (defense), the pattern of attack (offense), the transition from defense to offense (fastbreak), and the transition from offense to defense); (4) mental aspects (it is important to train basic mental skills, appearance $80 \%$ of an athlete's peak is influenced by mental aspects and only $20 \%$ by other aspects, so this mental aspect must be managed deliberately, systematically and with a plan [1]. Basketball is also a game that uses speed (feet and hands) and alacrity (overall body movements) at the right time [2].

Basketball competition requires not only technical aspects but also physical, strategic, and mental aspects. Good fundamental technical skills such as dribbling, passing, and shooting must be possessed by every athlete so that in implementing offense and defense strategies can be done and mastered well [3]. In a match for 4x10 minutes, athletes must have good physical and mental conditions to compete well [4]. Several techniques must be excelled in basketball games, apart from dribbling, passing, and shooting techniques. There are moving without the ball techniques such as cutting (V-cut, L-cut, back cut, rear cut, front cut, backdoor cut, slashing); screen settings such as screen (pick \& roll, give \& go, pick \& pop out, down the screen, back screen, cross-screen, curl, double screen, multiple screens, screen to screen); kick out; drive penetration and motion/pattern [5]. Besides, in the basketball game, there are five positions adjusted to the athlete's ability and characteristics, including position 1 (Point Guard / Playmaker), position 2 
(Small Forward), position 3 (Shooting Guard), position 4 (Power Forward), and position 5 (Post / Center).

The characteristics of the athletes and positions during matches differ, especially in the ability to master the physical, technical, strategic, and mental abilities. Training the physical, technical, strategic, and mental abilities of the athletes takes a long time. This process starts from anatomical adaptation to enhancing the development in every basketball aspect, both during training and competitions. Bompa stated that the basic abilities of athlete biomotor consist of strength, endurance, speed, coordination, and flexibility. In supporting achievement, the ability of biomotor components is very important for every athlete such as: endurance, muscle strength, speed, muscle explosive power, agility, flexibility, and balance [6]. Therefore, every athlete must have a good biomotor component. The difference in motor skills of each athlete must also be known by a coach, as explained by Arias-Estero et al., who stated that "The coaches' main focus should be on providing an appropriate learning environment in which participants can make decisions".

Physical condition is the foundation of sports achievement. The technique, tactics, and mentality of athletes will be developed properly if they have good physical qualities. A good physical condition can help athletes to achieve maximum performance. Therefore when doing technical, strategic, and mental exercises, the athlete will not be disturbed by physical problems. Physical exercise is important for all age groups in basketball. However, in each age group, athletes have different physical conditions. The physical condition must be enhanced properly and correctly according to the level of the age group. In physical condition, there are energy fitness and muscle fitness. Energy Fitness is a component of energy sources that causes motion, while muscle fitness is the whole of the biomotor components, which include strength, endurance, speed, power, flexibility, balance, and agility [7]. Athletes with good biomotor will show good performance in the competition.

Biomotor is the ability of human movement influenced by the condition of the organ systems in the body. These organ systems include the neuromuscular system, respiration, digestion, blood circulation, energy, bones, muscles, ligaments, and joints. Therefore, if a basketball team wants to win a match, each athlete must have a good biomotor. The basic components of biomotor include several physical conditions such as endurance, strength, speed, coordination, and flexibility [8]. The development of biomotor components is a combination of physical conditions, such as stamina is a combination of endurance and speed, agility is a combination of speed and flexibility (flexibility), and power is a combination of strength and speed.

The main biomotor component in basketball is endurance, which the function is to determine the athlete's fitness level, so that the athlete able to produce maximum and stable performance throughout the match. Basketball athletes in the 16 year age group who have good endurance will get various benefits, such as will always be concentrated and focused throughout the game, will easily determine and change the rhythm of the game, and stay fit throughout the game. Endurance according to Sukadiyanto can be grouped into anaerobic endurance and aerobic endurance [9].

Another major biomotor component that plays a role in achieving the best performance in basketball is strength. Strength is applied when performing dribbling, passing, shooting, and other movements. According to Sukadiyanto strength is the ability the entire muscle system to contract in overcoming resistance or load. Athletes who have good strength will be able to follow all training programs and will be maximal in the competition. Strength training that is carried out continuously will produce strength as expected. 
Speed is the last major biomotor component in the most important basketball game. This is because basketball is a sport that requires speed, especially during the transition from defense to offense or the transition from offense to defense [10]. If an athlete has the ability to run or pass, the athlete has good defensive and offense technical skills.

The biomotor components of coordination, flexibility, power, and agility will be easily mastered if the biomotor components of endurance, strength, and speed have been mastered. From some of the explanations above, it can be concluded that good physical condition will have a function and role in the process of increasing performance and achievement in sports.

Based on the discussions above, it needs to know the biomotor components of basketball athletes, especially basketball athletes in the 16 year age group. Therefore, we were interested in doing research on biomotor components in basketball athletes of the 16 year age group in the Cirebon region. The purpose of this study was to determine the biomotor profile of basketball athletes in the age group of 16 years old in the Cirebon Region. There were several biomotor components in this study such as endurance, strength, speed, coordination, flexibility, power, and agility.

\section{Method}

This study used a survey method which data collection techniques using tests and measurements. The survey method is one of the studies conducted by collecting information by compiling a list of questions for respondents. This study was conducted at the GMC Basketball Club, Cirebon City, with a population of athletes in the 16 year age group. This study used a total sampling, namely all athletes aged 16 year age group with male gender. This study analyzed how the Biomotor Profile of Basketball Athletes in the Age Group of 16 Years. The sample in this study was 20 basketball athletes in the 16 year age group. Biomotor profile data were collected by (1) an athlete's endurance test using the Multi-stages Fitness Test (MFT) or also known as the Bleep Test; (2) the athlete's strength test uses a push-up test, sit-up test, and back-up test; (3) the speed test using sprint running, the data is obtained using the 20-meter sprint running a test; (4) the coordination test uses a catch throw basketball by measuring the ability and speed of throwing catch within 15 seconds; (5) a flexibility test with the athlete performing sit and reach, (6) this power test the athlete performs a vertical jump test to determine the leg power during vertical jumps; (7) the agility test performed was the modified AAHPERD run test [26]. The results of the study are presented in five categories, namely very good, good, moderate, poor, and very poor.

\section{Result}

The results of the study on the Biomotor Profile variables of basketball athletes in the 16 year age group are presented in Table 1. 
Table 1. Frequency Distribution

\begin{tabular}{clcc}
\hline No & \multicolumn{1}{c}{ Test } & Percentage & Category \\
\hline 1 & Endurance test & $69.23 \%$ & Moderate \\
2 & Strength test & $38.46 \%$ & Good \\
3 & Speed test & $84.62 \%$ & Very good \\
4 & Coordination test & $38.46 \%$ & Moderate \\
5 & Flexibility test & $38.46 \%$ & Moderate \\
6 & Power test & $30.77 \%$ & Poor \\
7 & Agility test & $84.62 \%$ & Very good \\
\hline
\end{tabular}

Based on table 1 Biomotor Profile of Basketball Athletes in the 16 Years Age frequency distribution shows that endurance test of $69.23 \%$ was in the moderate category, strength test of $38.46 \%$ was in the good category, speed test of $84.62 \%$ was in the very good category, coordination test of $38.46 \%$ was in the moderate category, flexibility test of $38.46 \%$ was in the moderate category, power test of was in the poor category, agility test of $84.62 \%$ was in the very good category.

Biomotor Profiles of Basketball Athletes for the Age Group of 16 Years based on the T Score are presented in Table 2.

Table 2. Biomotor Profiles of Basketball Athletes in the Age Group of 16 Years Based on the T Score

\begin{tabular}{clcc}
\hline No & Category & Percentage & Total \\
\hline 1 & Very good & $15.38 \%$ & 3 athletes \\
2 & Good & $23.08 \%$ & 5 athletes \\
3 & Moderate & $38.46 \%$ & 7 athletes \\
4 & Poor & $15.38 \%$ & 3 athletes \\
5 & Very poor & $7.69 \%$ & 2 athletes \\
\hline
\end{tabular}

Biomotor Profile of Basketball Athletes in the 16 Years Age Group based on the T Score shows that $7.69 \%$ (2 athletes) was in the very poor category, $15.38 \%$ ( 3 athletes) was in the poor category, $38.46 \%$ ( 7 athletes) was in the moderate category, $23.08 \%$ (5 athletes) was in a good category, and $15.38 \%$ ( 3 athletes) was in the very good category. Based on the average value, it shown that the Biomotor Profile of Basketball Athletes in the 16 Years Age Group was in the sufficient category.

\section{Discussion}

This study aimed to determine the biomotor profile of basketball athletes in the 16 year age group. The biomotor variables be analyzed were: (1) the athlete's endurance test measured by the Multistage Fitness Test (MFT) or often called the Bleep Test; (2) the athlete's strength test measured by a push-up test, sit-up test, and back-up test; (3) the speed test measured by sprint running, the data was conducted using the 20-meter sprint test; (4) the coordination test measured by a catch throw basketball by measuring the ability and speed of throwing catch within 15 seconds; (5) the flexibility test measured by the sit and reach activity, (6) the power test measured by performing a vertical jump test to determine the leg power when making a 
vertical jump; (7) the agility test measured by the modified AAHPERD run test [11]. In other studies, the selected biomotor criterion such as leg strength was measured by using leg lift with dynamometer, speed was measured by conducting 50 meters dash, cardio-respiratory endurance was measured by using John Cooper's 12 minutes run/walk test and flexibility was measured by using sit and reach test. [12]

Every athlete must have their respective goals to get the achievement. The athletes must continue to train hard and follow a training program well to get better achievements. Regular training and proper training program will significantly improve the ability and performance of the athletes. It is not easy to develop the biomotor component of the athletes. The athletes must commit and follow the programmed training to have an excellent biomotor. Therefore, communication between coaches and athletes must properly be maintained, so that the results obtained during training will result in maximum performance [13].

\section{References}

[1] Harsono. Coaching dan Aspek-aspek Psikologis dalam coaching. Jakarta : PT Tambak Kusuma. 1988.

[2] Kosasih D. Fundamental Basketball, First Step To Win. Semarang: Karangturi Media.; 2010.

[3] Kurniawan, Fakhri Fajrin et. al., Development Model Training Shooting based on Multiple Unit Offense for Basketball Athletes 16-18 Years of Age Groups. International Journal of Multicultural and Multireligious Understanding (IJMMU). 2000; 7 (8).

[4] Sulasi, Endah Muhaima. Perkembangan Komponen Biomotor Atlet Bolabasket Putra Gunungkidul dalam Pekan Olahraga Daerah XIII Di Kulonprogo Tahun 2015. Yogyakarta: Universitas Negeri Yogyakarta. 2015.

[5] Sukadiyanto. Metodologi Melatih Fisik. Yogyakarta: Universitas Negeri Yogyakarta; 2010.

[6] Bompa, Tudor O., G. Gregor Haff. Periodization Theory and Methodology of Training. Dubuque, Jowa: Kendal/Hunt Publishing Company. 1983.

[7] Bambang Trisnowiyanto. Latihan Peningkatan Kemampuan Biomotor (Kelincahan, Kecepatan, Keseimbangan dan Fleksibilitas) dengan Teknik Lari (Shuttle Run, Zig-zag, Formasi 8) pada Pesilat. Jurnal Keterapian Fisik. 2016; 1(2): 82-89.

[8] Arias-Estero JL, Argudo FM, Alonso JI. One-on-one situation decision-making according to equipment in youth basketball. Int J Sports Sci Coach. 2018;13(1):72-7.

[9] Zhannisa H, Sugiyanto F. Model Tes Fisik Pencarian Bakat Olahraga Bulutangkis Usia Di Bawah 11 Tahun Di DIY. J Keolahragaan. 2015;3(1):117-126.

[10] Mega MR. Tingkat Biomotor Atlet POPDA Bola Voli Kabupaten Banjarnegara Tahun 2013. Universitas Negeri Yogyakarta; 2013.

[11] Donsu J. Metodologi Penelitian Keperawatan. Yogyakarta: Pustaka Baru; 2016.

[12] Education American Alliance for Health Physical, And Dance Recreation. AAHPERD skills test manual. Basketball for girls and boys. Reston: AAHPERD; 1984.

[13] Rajan, Nithin and Ahamed Faiz PA. Plyometric training on selected bio motor abilities of basketball players. International Journal of Physiology, Nutrition and Physical Education 2018; 3(1): 1296-1299 